\title{
Hydrogenation of Coal: a French Process
}

\begin{abstract}
$7 \mathrm{HE}$ hydrogenation of coal to produce liquid fuel is, as is known, a process now in technical operation. The French process as carried out at Béthune has been described by F. Vollette (Bull. Soc. d'Encouragement pour l'Industrie Nationale, 135, $353 ; 1936)$.

The coal and hydrogen must be brought into intimate contact by intense agitation, and the tem. perature must be increased progressively by passing the mixture through zones, sufficient time being allowed at $350^{\circ}$ for pasty fusion and solution in the oil, and at higher temperatures up to $470^{\circ}$ for the absorption of hydrogen. The apparatus consists of a bundle of long narrow tubes (faisceau tubulaire) united to one another by interior pipes like gas washing bottles, through which the hydrogen bubbles. The whole is heated in a cell of a coke furnace. The finely powdered coal is suspended in heavy oil and pumped at $200 \mathrm{kgm}$. pressure into the apparatus, where it meets a current of hydrogen from a compressor.

The volatile product, by cooling under pressure and removal of gas, is automatically divided into gas, heavy oil (at $300^{\circ}$ ) and light oil (atmospheric temperature). Very light petrol (5 per cent of the total light oil) is removed from the gas by adsorption on
\end{abstract}

active carbon. Part of the gas is used for heating and part is mixed with the hydrogen. The heavy oil is used for the suspension of coal. The non-volatile product is partly hydrogenated with the heavy oil and partly carbonized to coke for making water-gas. The hydrogen is obtained from water-gas and steam and need not be pure : even coke-oven gas (50 per cent $\mathrm{H}_{2}$ ) may be used.

The overall yield of light oil is given as $660 \mathrm{kgm}$. per metric ton of coal, and it contains 25-30 kgm. of phenol and cresols. Of this oil, $87 \cdot 5$ per cent distils below $300^{\circ}$ and 27.5 per cent below $200^{\circ}$. The heavier fraction is further hydrogenated in the vapour phase under pressure in presence of a catalyst to give petrol, which is principally aromatic and hydro-aromatic. Lignite hydrogenates more easily than coal. From $660 \mathrm{kgm}$. of light oil, $460 \mathrm{kgm}$. of petrol are obtained, or 1 ton per $2 \cdot 175$ tons of coal. This requires $3,500 \mathrm{cu}$. $\mathrm{m}$. of hydrogen, in making which $2 \cdot 2$ tons of coke are used. The steam used requires I ton of coal per ton of petrol and the electrical energy for compression of gas and works service consumes a further 2 tons of coal. Thus $7 \cdot 375$ tons of coal are used in making 1 ton of petrol, the calorific value of which is 20.75 per cent of the total fuel used.

\section{Biology of Tridacna and its Relatives}

$\mathrm{T}$ HE largest bivalves in the world belong to the Tridacnidæ. They have always aroused much interest in conchologists although little was known of the living animals. Size is not the only distinction in the family, for Prof. C. M. Yonge* shows that they are unique among the Lamellibranchiata. in the relation of the mantle and shell to the other organs, and in the universal presence of zooxanthellæ in the tissues. In his peculiarly interesting monograph, there is a large amount of new matter clearing up much that was puzzling in these gigantic molluses, which are among the most conspicuous members of the fauna of coral reefs in the Indo-Pacific region. Tridacna derasa, the giant clam, may be $4 \frac{1}{2} \mathrm{ft}$. long : the largest lamellibranch ever evolved, and may weigh about $4 \mathrm{cwt}$. The largest specimens personally examined were a little more than $3 \mathrm{ft}$. in length, and were so heavy that the combined efforts of two men failed to raise them.

There are two groups in the Tridacnidæ, the smaller boring forms, living in coral rock, and the larger species lying free on the surface of the reefs. All these clams normally rest on the hinge side of the shell with the edges of the valves pointing upwards. The pedal aperture, when present, lies close to the umbo. Thus, "as a result of a turning move-

- British Museum (Natural History). Great Barrier Reef Expedition, 1928-29. Scientifle Reports, Vol. 1, No. 11: Mode of Life, Feeding, Digestion and Symbiosis with Zooxanthellm in the Tridacnidig. By Prof. C. M. Yonge. Pp. 283-321 +5 plates. (London : British Museum (Natural History), 1936.) 58. ment in the longitudinal plane, the dorso-ventral relations of the visceral mass and associated organs, on the one hand, and of the mantle and shell on the other, have become ... the exact opposite of those in other lamellibranchs". This has given rise to much controversy as to whether the visceral mass has moved relative to the shell or whether the mantle has moved relative to the visceral mass. Prof. Yonge is now in the position to prove that the latter supposition is correct, and in this he is in agreement with Lacaze-Duthiers.

It is, however, in the amazingly efficient partnership with the zooxanthellæ that these molluses are of outstanding interest. On this depends the whole problem of feeding, structure and evolution. Immense numbers of these zooxanthellæ always occur in the Tridacnidæ, housed primarily in the blood cells of the inner lobes of the mantle edges on the dorsal side where they are fully exposed to the light. In Tridacna these lobes extend far over the free edges of the shell valves in life, exposing a broad sheet of highly pigmented tissue. In the allied Hippopus, where there are fewer zooxanthellæ, the mantle edges do not extend in this way, but the shell valves open to a greater extent. The zooxanthellæ are confined to the blood sinuses, and are invariably contained within amcboid blood cells. Conical protuberances on the mantle edge, carrying lens-like structures, hitherto regarded as eyes, are here shown to be means whereby the internal illumination of the mantle 
tissues is increased for the benefit of the zooxanthellæ. The phagocytes, carrying the zooxanthellæ from the mantle, surround the reduced diverticula and other regions of the gut and contain these algæ in all stages of digestion. Tridacna, and to a less extent Hippopus, consumes a number of these, so obtaining a significant amount of food.

The mouth is small, there is no sorting mechanism in the stomach, and the selective action of the gills and palps is highly developed, particles $14 \mu$ in diameter being rejected. Assimilation and intercellular digestion take place in the much-reduced digestive diverticula and also in the phagocytic blood cells which may pass through the lumen of the gut. Indigestible material remaining in the phagocytes is presumably carried to the kidneys, which explains the abnormal size of these and the presence within them of a great number of large concre. tions.

The Tridacnidæ are profoundly modified for the housing and final digestion of the zooxanthellæ, and Tridacna may be considered the supreme example of the exploitation of associated algæ by an animal, although unlike Convoluta, roscoffensis it never loses the power of holozoic nutrition, and so only the surplus zooxanthellæ are consumed. Experiments failed to reveal any significant production of oxygen or removal of carbon dioxide by the zooxanthellæ in the light, but they automatically remove all phosphorus excreted by the animal and even the phosphorus present in the water around. This may be the limiting factor controlling their abundance.

In no case known where there is a partnership of algæ with an animal has it been so highly evolved as in Tridacna, resulting in the actual farming of the zooxanthellæ by the mollusc. Every stage in the evolution shows a step towards this end. In a Cardium-like ancestor, it is suggested that the zooxanthellæ first settled in the region of the siphons, having been taken in with the food and so ingested by wandering phagocytes. This partnership being of advantage to both alga and molluse, but especially to the latter, the molluse became so modified in structure that the largest possible surface might be exposed in which the algæe could dwell near the light, whilst with a larger consumption of these the ordinary digestive organs were more and more reduced, a very good combined method of feeding being the result, the boring forms having evolved after this adaptation of structure and functions. It is found that boring is entirely mechanical and that the byssus takes an essential part in this process.

\section{Bacterial Epidemiology and Nutrition}

A TEAM of statisticians and bacteriologists who for many years have been investigating experimentally the spread of epidemics of bacterial diseases caused by Bacterium aertrycke and Pasteurello muriseptica in herds of mice under controlled conditions, have now summarized the results of their published work with the addition of some new observations, including an account of epidemics of ectromelia, a virus disease of mice ${ }^{1}$.

To the epidemiologist the work is of great interest and value, and many important conclusions emerge from it. It is found that the average resistance of surviving mice increases with survival in a herd, but never becomes absolute, and in the long run the great majority eventually succumb to the reigning disease, nor will the disease ever normally die out provided the herd does not become too small. The increased average resistance displayed by surviving mice is attributed to natural immunization.

It is considered proved that artificial immunization does confer a high degree of resistance, being more effective in a virus condition like ectromelia than in a bacterial disease like mouse typhoid. Experiments on the influence of 'bacteriophage' on mouse typhoid yielded entirely negative results. It is considered that a major importance may be attached in the genesis of epidemics to the evolution or importation of 'epidemic strains' of particular bacteria or viruses, and that association of two infecting agents may play a part in determining the character of an epidemic.

It seems to be clear that the amelioration or disappearance of an endemic or epidemic infection is more often the result of a summation of effects, many of them unidentifiable, than of any single known factor.
Mr. Knight has recently brought together in convenient form the available information respecting bacterial nutrition ${ }^{2}$. Knowledge of the conditions favouring or inhibiting bacterial development is of importance in bacteriological technique and in the study and control of infective diseases and morbid states, as well as indicating relationships which suggest the possible evolutionary scheme of the bacteria, particularly as it relates to parasitism.

The report is divided into three parts, of which the first and longest gives a systematic survey of the known facts, and summarizes the chemistry of bacterial metabolism and the nutritional requirements of bacteria. In the second part, these nutritional observations are co-ordinated, a brief attempt is made to develop an evolutionary scheme, and the parallelism between nutrient requirements and the development of pathogenic properties and parasitism is illustrated. In the final part, methods are described by which bacteria may be 'trained' and 'adapted' to a simpler mode of life, and the mechanism of nutritional variation is discussed.

There is much in Mr. Knight's report of interest to the general bacteriologist, such as his critical review of the gaseous requirements of bacteria, the various methods that may be employed for the study of bacterial metabolism, and the differentiation of essential from accessory food substances in relation to bacterial growth.

1 Medical Research Council. Special Report Series, No. 209: Experimental Epidemiology. By Dr. M. Greenwood, Dr. A. Bradford Hill, Dr. W. W. C. Topley and J. Wilson. Pp. 204. (London : H.M. Stationery Office, 1936.) 3s. $6 d$, net.

- Medical Research Council. Special Report Series, No. 210 : Bacterial Nutrition; Material for a Comparative Physiology of Bacterial Nutrition; Material for a Comparative Physiology of
Bacteria. By B. C. J. G. Knight. Pp. 182. (London: H.M. Stationery Bacteria. By B. C. J. C. 